\title{
Sewage Water Treatment Analysis Using Activated Charcoal in Packed Column
}

\author{
Adeloye Olalekan Michael ${ }^{1, *}$, Ene Peter Meshack², Cyrus Aseibichin ${ }^{3}$ \\ Department of Chemical/Petrochemical Engineering, Rivers State University, Port Harcourt, Nigeria \\ Email address: \\ adeloye.olalekan@yahoo.com (A. O. Michael), ene.peter@ust.edu.ng (E. P. Meshack), maxvill2011@yahoo.com (C. Aseibichin) \\ ${ }^{*}$ Corresponding author
}

\section{To cite this article:}

Adeloye Olalekan Michael, Ene Peter Meshack, Cyrus Aseibichin. Sewage Water Treatment Analysis Using Activated Charcoal in Packed Column. Journal of Energy, Environmental \& Chemical Engineering. Vol. 6, No. 3, 2021, pp. 65-70. doi: 10.11648/j.jeece.20210603.13

Received: May 31, 2021; Accepted: June 18, 2021; Published: July 27, 2021

\begin{abstract}
The research study analyzed sewage water from Eagle Island Nkpolu-Oroworukwo community, Port Harcourt and its treatment with activated charcoal for its re-application. The water sample collected was analyzed experimentally for both untreated and treated samples to determine pH, Total Dissolved Solid (TDS), Total Suspended Solid (TSS), Total Solid, Total Hardness, Biological Oxygen Demand (BOD), Chemical Oxygen Demand (COD), Phosphate $\left(\mathrm{PO}_{4}\right)$, and $\left.\mathrm{Nitrate}_{(\mathrm{NO}}\right)$. Also, water quality index (WQI) and status of water was also investigated to know the quality of untreated and treated water sample by analyzing ten parameters based on the recommended standards of the World Health Organization (WHO), Nigerian Industrial Standards (NIS) and Federal Environmental Protection Agency (FEPA) for water quality. The water quality index values for the untreated and treated samples are 108.213 and 40.024 respectively. The values of the water quality index showed that the untreated sewage water belongs to grade E, hence its unsuitability while that of the treated water sample showed a good quality water as it belongs to grade B that falls between the range of $25-50$. Thus, water quality index is applied as a tool for comparing water quality of different sources and locations and sewage water treatment with activated charcoal in a packed column is an effective tool for sewage water treatment.
\end{abstract}

Keywords: Sewage Water, Activated Charcoal, Water Quality Index, Organic Analysis, Solid Analysis, Nutrient Analysis

\section{Introduction}

Sewage or domestic wastewater or municipal wastewater is a kind of wastewater, which is generated within the community of people. Some of its inherent characteristics are volume or flow rate, physical condition, chemical and toxic constituents, and its bacteriologic status (presence of microorganisms and its amounts). It contains mainly of grey water (from sinks, tubs, showers, dishwashers, and clothes washers), black water (toilet flushing water in addition to flushing of human wastes); soaps and detergents; and toilet paper (less so in regions where bidets are widely used) and yellow water refers to mainly collection of urine from specific channels and not contaminated with either black water or gray water. Chemical characterization of municipal wastewater involved three main constituents, organic compounds, nitrogenous compounds and phosphorus. The organic compounds are carbohydrates, proteins and fats, while nitrogen is occur mainly as ammonia and existence or presence of phosphorus is due to phosphates from domestic waste. Municipal wastewater possess particulate constituents in dissolved form that include living biomass, grit, anions and cations. These constituents are treated at the wastewater treatment plant, thus characterization of the wastewater [1]. Furthermore, the Federal Environmental Protection Agency (FEPA) was established by the federal government of Nigeria by decree 58 in 1989 with its responsibilities including researching, setting standards, emission monitoring, and enforcement of laws governing pollutants emissions for all categories, which include solid waste, air and water. The world health organization (WHO) limited discharge of effluent into surface water was adopted as FEPA guidelines and the national interim effluent limited for discharge into surface water [2].

Wastewater treatment refers to reduction of contaminants in wastewater to an acceptable level such that the water can 
be channeled back safely to the environment. The aim of wastewater treatment is the removal of microorganisms causing diseases, pollution prevention and protection of public health and the environment [3]. Techniques for treating wastewater were developed first in response to the harsh conditions caused by wastewater discharge to the environment and public health concerns. Besides, due to urbanisation, availability of land for treating wastewater and its disposal were limited, principally by irrigation and intermittent filtration. In addition, increase in population increases the amount of wastewater produced rapidly and the deteriorating quality of this large amount of wastewater exceeded the self-purification capacity of the streams and river bodies [4]. Hence, different treatment techniques were developed to promote the forces of nature under controlled conditions in treatment facilities of comparatively smaller size. Generally, between 1900 and early 1970s, treatment objectives focused on the removal of suspended and floatable material from wastewater, removal of biodegradable organics and elimination of disease-causing pathogenic organisms. Also, between early 1970 and 1990s, the objectives of treating wastewater focused mainly on aesthetic and environmental concerns [5]. The earlier objectives of reducing and removing of $\mathrm{BOD}$, suspended solids, and pathogenic micro-organism continued, but at higher levels. Removal of nutrients (nitrogen and phosphorus) also started to be addressed, particularly in some of the streams and lakes. Major initiatives were implored around the world, to achieve more efficient and widespread treatment of wastewater to enhance surface waters quality [6] This effort was due to an improved knowledge of the environmental effects caused by wastewater discharges and developing understanding of the adverse long term effects caused by the discharge of some of the specific constituents found in wastewater. Since 1990, due to improved scientific knowledge and an enlarged information base, treatment of wastewater has started to focus on the health concerns related to toxic and potentially toxic chemicals released into the environment. The objectives of improving water quality of the 1970s have continued, but the main focus has shifted to the definition and treatment of toxic and trace compounds, which could cause long-term health issues and negative impacts on the environment. Therefore, while the objectives treatment methods remains valid, the required extent of treatment has increased progressively and more treatment objectives and focuses have been included [7]. Hence, the aim of this research study is to analyze sewage water from Eagle Island Community, Nkpolu-Oroworukwo, Port Harcourt City Council, Rivers State, Nigeria to determine its contents and its treatment with activated carbon, to make the sewage water fit for reuse. This aim will be achieved by evaluating the sewage water sample to determine its contents, its treatment by using activated carbon, deduction of sewage sample water quality index before and after sample treatment for environmentally friendly safe fluid waste stream.

\section{Materials and Experiments}

Sewage water sample applied in this research study was taken from Eagle Island Community, Port Harcourt, Rivers State, and sample was transferred carefully to cleaned containers to prevent contaminations and analyzed at the Chemical/Petrochemical Engineering Department Laboratory, Rivers State University, Port Harcourt. The sample experimental analysis was performed to determine organic analysis such as biochemical oxygen demand, chemical oxygen demand and oil and grease, solid analysis such as total solid, total suspended solid and total dissolved solid, nutrient analysis such as test for nitrates and phosphate, and other analysis such as $\mathrm{pH}$ test and chlorine test.

\subsection{Biochemical Oxygen Demand}

Biochemical Oxygen Demand test is used to evaluate organic matter's concentration in sample of wastewater due to the availability of sufficient oxygen, biological decomposition (organic waste stabilization) by aerobic microorganisms will continue until all waste is consumed. The experimental procedure involved the application of specialized $300 \mathrm{~mL}$ BOD bottles designed with no air space, thereby providing an airtight seal and sample to be tested is introduced into the bottles or dilution (distilled or deionized) water and different quantities of the wastewater sample are added to reflect various dilutions, and with a control dilution water bottle. The concentration $(\mathrm{Mg} / \mathrm{L})$ of dissolved oxygen in each bottle ab initio was measured by a DO meter and then, the bottles are placed into a dark incubator at $20^{\circ} \mathrm{C}$ for five days. After five days, the final concentration $(\mathrm{Mg} / \mathrm{L})$ of dissolved oxygen was measured by a DO meter and final DO value was subtracted from the initial $D O$ value and the resulted value yielded concentration of the BOD $(\mathrm{Mg} / \mathrm{L})$. A dilution factor is used to multiply the DO final value for a diluted wastewater to determine its BOD concentration $(\mathrm{Mg} / \mathrm{L})$. Hence, Biochemical Oxygen Demand is evaluated as shown.

$$
B O D_{5}=\frac{D O_{i}-D O_{f}}{P}
$$

\subsection{Chemical Oxygen Demand}

Chemical Oxygen Demand is performed on the sample to evaluate the degree of readily oxidizable organic matter that is biologically oxidizable and biologically inactive. The experimental procedure involved the preparation of 100, 250, 500 and $1000 \mathrm{Mg} / \mathrm{L}$ using KHP (potassium hydrogen phthalate) and COD reactor $\left(150^{\circ} \mathrm{C}\right)$ block and a colorimeter are turned on so that both instruments are allowed to stabilize. Then, prepared low-range (3-50 ppm) and high-range (20$1500 \mathrm{ppm}$ ) vials are selected for the COD test and a marked vial as a blank and three or four vials with known standard levels, two vials are then marked for the wastewater sample to make a duplicate and $2 \mathrm{ml}$ of liquid are added to each vial. Each vial is stirred appropriately and sent into the reactor block for two hours, after which the vials are removed from 
the block to a cooling rack for about fifteen minutes. The colorimeter is set and calibrated per wavelength for blank and standards, and each vial is placed in the unit and the COD concentration read. Hence, Chemical Oxygen Demand yields the required oxygen demand for the complete oxidation of both biodegradable and non-biodegradable matter and is evaluated as:

$$
C O D=\frac{(a \times b) \times 8000}{\text { volumeofsample }}
$$

\subsection{Oil and Grease}

Oil and grease refers to a certain related constituents, which are of importance in treating wastewater as a result of their unique physical properties and high concentration of energy content. It involved weighing of clean flask and addition of one litre wastewater sample that is acidified using hydrochloric or sulphuric acid to a $\mathrm{pH}$ of 2 . The acidified sample of wastewater is then moved into a $2 \mathrm{~L}$ separating funnel, and $30 \mathrm{ml}$ of normal hexane (extraction solvent) was added to the funnel and the funnel well stirred for two minutes. Then, wastewater/extraction solvent layers are allowed to separate in the funnel (the lighter water layer will be on the top and heavier extraction solvent at the bottom), and the extraction solvent is drained into the flask prepared earlier. Thus, the above extraction procedure was repeated twice to extract more oil and grease. Furthermore, the contents of the flask containing solution of the extraction solvent with oil and grease are heated so that the extraction solvent is distilled into another container, and the flask containing the extracted oil and grease is reweighed and the initial weight of the flask is subtracted and the total oil and grease weight was calculated.

\subsection{Total Dissolved Solids}

Solids in waste sample refers to suspended or dissolved materials in water or wastewater, which can be isolated physically by filtration or evaporation. Thus, total dissolved solids means completely dissolved substances in water, which can be separated by filtration and are residue upon evaporating of non-filterable sample on a filter paper. The procedure involved proper mixing of waste water sample and filtered in a filtrating funnel with filter paper and $80 \mathrm{ml}$ filtrate was achieved. $75 \mathrm{ml}$ of unfiltered sample was pippeted in the porcelain dish and placed in an oven regulated at $105^{\circ} \mathrm{C}$ and the sample is dried usually between 1 to 2 hours to eliminate necessity of checking for constant mass. The container is cooled in a desiccator and the dish weighed immediately to avoid absorption of moisture due to its hygroscopic nature. Total dissolved solid is determined by the expression

$$
\operatorname{TDS}(\mathrm{mg} / L)=\frac{\text { weightofdrysolid }(g)}{\text { volumeofsample }(L)} \times 10^{6}
$$

\subsection{Total Suspended Solids}

Total suspended solids are dry-weight of suspended particles, which are not dissolved in the sample water and can be filtered during filtration process. The experimental procedure involved thorough mixing of sewage water sample and pouring into graduated cylinder of desired volume, suction to filter flask and seat filter are applied with small amount of distilled water and sample is filtered with filtration apparatus and graduated cylinder is rinsed with three successive $10 \mathrm{ml}$ of distilled water and complete drainage is allowed between each rinsing. Suction is continued for three minutes after filtration of final rinse is completed, filter is dried in an oven between $103^{\circ} \mathrm{C}$ to $105^{\circ} \mathrm{C}$ for one hour, cool in desiccator at room temperature and filter and support weighted. Total suspended solids is evaluated as

$$
\operatorname{TSS}(\mathrm{mg} / L)=\frac{\text { weightofdrysolid }(\mathrm{g})}{\text { volumeofsamplefiltered }(L)} \times 10^{6}
$$

\subsection{Total Solids}

Total solids are completely dissolved materials in water. These solids can be filtered in nature and as residue upon evaporating of non-filterable sample on a filter paper. It involved proper mixing of waste water sample and $5 \mathrm{ml}$ is pipeted into a clean, dried and known weight porcelain crucible. A steam bath was applied to dry off water for one hour, the crucible was cooled and weighed. The relationship among total solids, total suspended solids and total dissolved solids is expressed as

$$
T S=T S S+T D S
$$

\subsection{Nutrient Analysis}

The nutrient analysis performed in this research study tested for nitrates and phosphates contents of the waste water sample. The nitrate test involved pipetting $25 \mathrm{ml}$ of the sewage sample into an evaporation dish and evaporated almost to dryness. It was then cooled, and $0.5 \mathrm{ml}$ phenoldisulphonic acid and $5 \mathrm{ml} \mathrm{KOH}$ was added and swirl gently and transferred carefully into $25 \mathrm{ml}$ volumetric flask, made up to the mark with distilled water and its absorbance at 420 $\mathrm{nM}$ was measured. Also, the phosphate test involved placing $40 \mathrm{ml}$ of sewage water sample in a $50 \mathrm{ml}$ stopper volumetric flask. Then, the flask and standard samples were taken and 8 $\mathrm{ml}$ of the mixed reducing agent diluted with $50 \mathrm{ml}$ water and mixed properly. The solution settled for 10 minutes, and the optical density of the coloured solution was measured with a suitable spectrophotometer. In addition, chlorine content was also analysed by measuring $50 \mathrm{ml}$ of waste water sample in flask and add $0.5 \mathrm{ml}$ of Potassium chromate. This is titrated against silver nitrateand the average titre value determined. The choride content is evaluated using

$$
\mathrm{Cl}^{-}(\mathrm{mg} / \mathrm{L})=\frac{\text { Titrevalue } \times 0.1 \times 35,500}{\text { Volumeofsample }(\mathrm{ml})}
$$

\section{8. $p^{H}$}

$\mathrm{p}^{\mathrm{H}}$ measures the hydrogen ion concentration of a solution and it shows the intensity of acidity or alkalinity of the solution, with its value ranges between zero and 14 . The $\mathrm{p}^{\mathrm{H}}$ 
of the sewage sample was measure using a $\mathrm{p}^{\mathrm{H}}$ meter.

\subsection{Waste Water Treatment}

The waste water sample was treated with activated carbon and the treatment procedures involved $200 \mathrm{~g}$ and $100 \mathrm{~g}$ of activated carbon and sharp sand were weighed and poured into a container respectively. The sand is sieved with a melsh size of $0.4 \mu \mathrm{m}$ for fine particles and washed to remove dirts and dried. A column size is set up using retort stand and clamp with a hose attached for receiving. Cotton wool is inserted into the set up column close to $4 \mathrm{~mm}$ away from the bottom, sharp sand is poured into the column at $3 \mathrm{~mm}$ from the cotton wool and $200 \mathrm{~g}$ of measured activated carbon is added into the column at considerable length and sharp sand is poured into the column at $4 \mathrm{~mm}$ from the activated carbon. Thus, a packed column is achieved for the treatment process and this column is cleansed using one liter of distilled water, and the waste water sample is poured into the column for treatment.

Table 1. Water Standard and Unit Weight [2, 8].

\begin{tabular}{lllll}
\hline S/N & Parameters & Standards & Recommended Agency & Unit Weight \\
\hline 1 & $\mathrm{P}^{\mathrm{H}}$ & $6.5-8.5$ & NIS/FEPA & \\
3 & Total Dissolved Solids & 500 & NIS/WHO & \\
& Total Solid & 530 & & \\
& Total Suspended Solid & 30 & FEPA & 0.025899 \\
& Total Hardness & 30 & WHO & 0.007338 \\
4 & Chloride & 600 & FEPA/BIS & 0.007338 \\
5 & Chemical Oxygen Demand & 40 & FEPA & 0.0003669 \\
6 & Biological Oxygen Demand & 10 & FEPA & 0.055035 \\
7 & Phosphate & 5 & FEPA & 0.022014 \\
8 & Nitrate & 50 & NIS & 0.044028 \\
\hline
\end{tabular}

\subsection{Water Quality Index}

In evaluating the water quality index, ten different parameters of the recommended standard by the World Health Organization (WHO), Nigerian Industrial Standards (NIS) and Federal Environmental Protection Agency (FEPA) for water quality were followed and the weighted arithmetic index method applied for the its evaluation and followed by quality rating or sub index $\left(q_{n}\right)$ [9]. The steps involved in evaluating water quality index is described thus with acceptable standards and status.

The unit weight $\left(\mathrm{W}_{\mathrm{n}}\right)$ was calculated by the expression

$$
W_{n}=\frac{K}{S_{n}}
$$

The constant of proportionality is therefore determined as

$$
K=\frac{1}{\Sigma\left(1 / s_{n}\right)}
$$

The quality rating $\left(q_{n}\right)$ was calculated by

$$
q_{n}=\frac{c_{n}}{s_{n}}
$$

The WQI was calculated by the equation

$$
W Q I=\frac{\sum\left(q_{n} W_{n}\right)}{\sum W_{n}}
$$

Table 2. Water Quality Index and Status [10, 11].

\begin{tabular}{lll}
\hline Water Quality Index & Water Quality Status & Grade \\
\hline $0-25$ & Excellent water Quality & $\mathrm{A}$ \\
$26-50$ & Good water Quality & $\mathrm{B}$ \\
$51-75$ & Poor water Quality & $\mathrm{C}$ \\
$76-100$ & Very poor water quality & $\mathrm{D}$ \\
Above 100 & Unsuitable water quality & $\mathrm{E}$ \\
\hline
\end{tabular}

\section{Results}

The results obtained from the sewage water laboratory analysis before and after treatment with activated charcoal in a packed column bed are shown in Table 3. Also, the result of water quality index analysis for untreated and treated water samples are highlighted in Tables 4 and 5 respectively.

Table 3. Analysis Result of Untreated and Treated Water Sample.

\begin{tabular}{llll}
\hline SN & Parameters & Untreated Sample & Treated Sample \\
\hline 1 & pH & 6.70 & 6.84 \\
2 & TDS & 220 & 122.5 \\
3 & TS & 220.43 & 122.75 \\
4 & TSS & 0.43 & 0.25 \\
5 & Total Hardness & 33 & 27.5 \\
6 & Chloride & 22.70 & 10.87 \\
7 & COD & 32 & 11.2 \\
8 & BOD & 26.67 & 6.33 \\
9 & Phosphate & 4.08 & 0.96 \\
10 & Nitrate & 13.5 & 11.35 \\
\hline
\end{tabular}

\section{Discussion}

\subsection{Experimental Analysis}

The value of $\mathrm{pH}$ reading is a pertinent tool that describes water suitability for different purposes, the $\mathrm{pH}$ concentration of the treated water sample is within allowable limits for surface water [12]. TDS in drinking water is associated with natural source, sewage, industrial wastewater, urban run-off and chemical used in water treatment process [13] thus, TDS in both untreated and treated water samples are within the recommended standards for drinking water as highlighted in Table 1. Hardness of water is described as the ability of water to cause precipitation of insoluble calcium and magnesium salts of 
higher fatty acids from soap solutions. Thus, calcium, magnesium bicarbonate, carbonate, chloride and sulphate are the major hardness causing ions [14]. The treated sample water hardness value fell drastically below its standard value in tandem with the chloride ion as a measure of low level of organic pollution. In addition, pollution of surface and ground water can be accessed, the water sample treated yielded a low value of BOD as compared with the standard value and the nutrients analysis yielded a low value of nitrate and phosphate compound, which shows that the treated water sample water does not possess eutrophication features as high nutrients $\left(\mathrm{NO}_{3}\right.$ and $\mathrm{PO}_{4}$ ) level often recorded in water bodies is a reflection of direct discharge of pollutants among which domestic and wood wastes rank high directly into the creek [15].

Table 4. Water Quality Index for Untreated Sewage Water Sample.

\begin{tabular}{|c|c|c|c|c|c|c|}
\hline $\mathbf{S} / \mathbf{N}$ & Parameters & Observed Value & $S_{n}$ & $W_{n}$ & $q_{n}$ & $W_{n} q_{n}$ \\
\hline 1 & $\mathrm{pH}$ & 6.7 & $6.5-8.5$ & 0.182312 & 62.32 & 11.36267 \\
\hline \multirow[t]{2}{*}{2} & TDS & 220 & 500 & 0.00392 & 44 & 0.172467 \\
\hline & $\mathrm{TS}$ & 220.43 & 530 & 0.003698 & 41.59 & 0.153795 \\
\hline 3 & Total Hardness & 33 & 30 & 0.065328 & 110 & 7.186113 \\
\hline 4 & Chloride & 22.7 & 600 & 0.003266 & 3.78 & 0.012358 \\
\hline 5 & COD & 32 & 40 & 0.048996 & 80 & 3.919698 \\
\hline 6 & BOD & 26.67 & 10 & 0.195985 & 266.7 & 52.26917 \\
\hline 8 & Nitrate & 13.5 & 50 & 0.039197 & 27 & 1.058318 \\
\hline \multicolumn{4}{|c|}{ Summation $\left(\sum\right)$} & 1 & & 108.213 \\
\hline
\end{tabular}

Table 5. Water Quality Index for Treated Sewage Water Sample.

\begin{tabular}{|c|c|c|c|c|c|c|}
\hline $\mathbf{S} / \mathbf{N}$ & Parameters & Observed Value & $S_{n}$ & $W_{n}$ & $q_{n}$ & $W_{n} q_{n}$ \\
\hline 1 & $\mathrm{P}^{\mathrm{H}}$ & 6.84 & $6.5-8.5$ & 0.182312 & 63.62791 & 11.6001 \\
\hline 2 & TDS & 122.5 & 500 & 0.00392 & 24.5 & 0.096033 \\
\hline 3 & TS & 122.75 & 530 & 0.003698 & 23.16038 & 0.085643 \\
\hline 5 & Total Hardness & 27.5 & 30 & 0.065328 & 91.66667 & 5.988428 \\
\hline 6 & Chloride & 10.87 & 600 & 0.003266 & 1.811667 & 0.005918 \\
\hline 7 & COD & 11.2 & 40 & 0.048996 & 28 & 1.371894 \\
\hline 8 & BOD & 6.33 & 10 & 0.195985 & 63.3 & 12.40584 \\
\hline 10 & Nitrate & 11.35 & 50 & 0.039197 & 22.7 & 0.889771 \\
\hline \multicolumn{4}{|c|}{ Summation $\left(\sum\right)$} & 1 & & 40.024 \\
\hline
\end{tabular}

\subsection{Water Quality Index and Status}

It can be deduced from Tables 4 and 5 that water quality index values for untreated and treated samples are 108.213 and 40.024 respectively, and these showed that there are variations in samples physicochemical variables studied. The water quality index value for the untreated sample is above 100 , thus belonging to grade $\mathrm{E}$ and making it unsuitable for any application and usage. Furthermore, the treated water sample yielded a vast decline in water quality index value from 108.213 to 40.024 as compared with untreated sample thereby falling within the range (26-50) of grade B that depicts good water quality. Thus, the treated sewage water is good and safe for human activities based on the standards of the water quality index (WQI).

\section{Conclusion}

The research analysis showed a high degree of operational efficiency in the treated water sample based on the water quality index result, which is an effective determinant factor (Table 2) of water quality. The high reduction or decline in the value of water quality index for treated water sample (from 108.213 to 40.024 ) showed a good treatment analysis was performed by using activated charcoal as an absorbent in a packed bed column. Also, the experimental studies on BOD, COD, test for oil and grease, TD, TSS, TDS, nutrient analysis, chloride and $\mathrm{p}^{\mathrm{H}}$ yielded results that are within the allowable WHO, NIS and FEPA standards for treated water sample, which also showed the acceptability and efficiency of the treatment process for safe and good quality water.

\section{Nomenclature}

$K$ : Constant of proportionality

$S_{n}$ : Standard value of the $\mathrm{n}^{\text {th }}$ parameter

$C_{n}$ : Concentration of parameter in sample

$q_{n}$ : Quality rating of the $\mathrm{n}^{\text {th }}$ parameter

$W_{n}$ : Quality unit weight of the $\mathrm{n}^{\text {th }}$ parameter.

$D O_{i}$ and $D O_{f}$ : Initial and Final dissolved oxygen concentration of the diluted sample

$P$ : Dilution factor and it is the ratio of sample volume (volume of wastewater) to total volume (wastewater plus dilution water).

a: Titrant sample

b: Blank sample 


\section{References}

[1] Wentzel, M. L., Ekama, G. A., \& Sotemann, S. W. (2006). Mass Balance Based Plant Wide Wastewater Treatment Plant Models-Part 1Biodegradability of Wastewater Organic Under Anaerobic Conditions, Water S. A, 32, 3, 269. 276.

[2] Federal Environmental Protection Agency (FEPA) (1991). Guidelines and Standards for Environmental Pollution Control in Nigeria. Lagos: Imprint, 210-220.

[3] Caribbean Environmental Health Institute (1998). Water Resources Management, United Nations Convection to Combat Desertification.

[4] Spellman, F. R. (2000). Spellman's Standard Handbook Wastewater Operators, Advanced Level. $10.1201 / 9781482278910$.

[5] Zhou, H. \& Smith, D. W. (2002). Advanced Technologies in Water and Wastewater Treatment, Journal of Environmental Science, 1, 247-264.

[6] Barbosa, R. A. \& Santama, G. L. (1989). Treatment of Raw Domestic Sewage in an UASB Reactor, Water Resources, 23, 1483-1490.

[7] Metcalf \& Eddy (1991). Wastewater Engineering Treatment, Disposal and Re-use. Singapore: McGraw-Hill Incorporated, 107-125.

[8] World Health Organization (WHO) (1992). International Standards for Drinking Water Quality. World Health Organization, Geneva, Switzerland.
[9] Brown, R. M., McClelland, N. I., Deininger, R. A. \& Tozer, R. G. (1970). Water Quality Index- Do We Dare? Water Sewage Works, 117, 10, 339-343.

[10] World Health Organization (WHO) (2004). Guidelines for Drinking Water Quality. Geneva: World Health Organization.

[11] Horton, R. K. (1965). An Index Number System for Rating Water Quality. Journal of Water Pollution Control Federation, $3,37,300-305$.

[12] Chandaluri, S. R., Sreenivasa, R. A., Hariharann, V. L. N \& Manjula, R. (2010). Determination of Water Quality Index of some Areas in Guntur district Andhra Pradesh, International Journal of Applied Biology and Pharmaceutical Technology, 1, 79-86.

[13] Asuquo, J. E. \& Etim, E. E. (2012a). Water Quality Index for Assessment of Borehole Water Quality in Uyo Metropolis, Akwa Ibom State, Nigeria. International Journal of Modern Chemistry, 1, 3, 102-108.

[14] Asuquo, J. E., \& Etim, E. E. (2012b). Physicochemical and Bacteriological Analysis of Borehole Water in Selected Areas in Uyo Metropolis. International Journal of Modern Chemistry, 2, 1, 7-14.

[15] Harbel, H. Erb, K. H., Krausmann, F., Gaube, V., Bondeau, A., Plutzar, C., Gringrich, S., Lucht, W., Fischer-Kowalski, M. (2007). Quantifying and Mapping the Human Appropriation of Net Primary Production in Earths Terrestrial Ecosystems, Proceedings of the National Academy of Sciences of the United State of America, 104, 3, 12945-12947. 